\title{
THE JEWISH ARCHITECT ZOLTÁN EGRI AND HIS WORK
}

\section{ZUZANA RAGULOVÁ}

Brno University of Technology, Faculty of Architecture, Poříčí 5, 63900 Brno, Czech Republic Tutor: prof. Ing. arch. Vladimír Šlapeta, DrSc.

Theme of the dissertation: Jewish architects in Brno 1918-1939

xaragulova@fa.vutbr.cz

\begin{abstract}
Zoltán Egri (born 1894) belonged to the group of interwar Jewish architects in Brno. Almost all of them studied at the German Technical University in Brno and were active mainly in the 1930s, focusing primarily on a Jewish clientele. Egri specialized in interior design and shopfronts. Some of them were destroyed or rebuilt, others preserved. In my paper, I will discuss not only his particular designs but also general specifics of his work and often-used materials.
\end{abstract}

KEY WORDS: Brno Jewish architects, interwar shopfront, interwar interior

\section{Jewish architects in Brno}

Zoltán Egri was one of a group of Jewish architects living in Brno in the interwar period. There were around 20 architects of Jewish origin in Brno at that time. This number is high compared to Prague or Bratislava and there are various reasons why it is so. Apart from the progressiveness of the city, which was open to modern structures, there was also a building boom in Brno at that time, as well as a large number of Jewish entrepreneurs providing work for the architects.

After World War I, a group of young Jews came to Brno to study architecture at the German Technical University. Some of them (like Zoltán Egri and Sigmund Kerekes) came from Hungary. Due to numerus clausus, Hungarian universities only accepted 
a limited number of students, and most of the applicants had to seek their education abroad.(1) In my paper I will focus on Zoltán Egri and his work.

\section{Life and early career}

Zoltán Egri was born to a Jewish family on 28th January 1894 in Eger. After graduation from Eger High School, in 1920 he moved to Brno and enrolled at the German Technical University, completing his studies in 1923. From 1925, he was a partner in the company Watterich Egri \& Co. Brünn.(2) Regarding his personal life, we don't know much. Egri's wife was called Jolánka and they had a daughter called Suse.(3) In the 1930s the whole family was living at Úvoz street 17. (4)

Apart from a short life biography and the incomplete list of his work, there are just two articles dedicated to Egri's work and some mentions can also be found in other articles (see bibliography). All of them are useful mostly because of the photos of the architect's work. In Horizont magazine from 1931, German architect Vinzenz Baier(5) describes Egri as the designer of creative and original decoration for a school carnival party. Most of the projects we know are from the 1930s, but from the article, it can be assumed that in the 1920s Egri designed mainly festive decorations and interiors. The architect is described as a brilliant draughtsman, talented and diligent, with the ability to fulfill the clients' wishes, but at the same time creating designs with his artistic expression. Egri is known mainly as an interior designer, architect of modern shopfronts, and the creator of a couple of exhibitions.

\section{Exhibitions}

In 1928, the Exhibition of Contemporary Culture in Czechoslovakia was held in Brno. The German Werkbund Pavilion was designed by German architect Vinzenz Baier and the interiors by Zoltán Egri and Othmar Frass-Friedenfeldt. Apart from the whole concept of the Werkbund exhibition, Egri designed the Textile department and German - Moravian Association section. As far as we can see from photos, it consisted of exhibition cabinets, chairs, sofa, lamps, wooden staircases, etc.(7) After designing the Werkbund Pavilion, Egri became better known in public and received more commissions.

In 1931, the Jewish community of Mikulov bought Skutetzky house, and in 1934 decided to provide the building to set up a new Jewish museum. Egri was asked to adapt the building and create the exhibition. On 24th May 1936, the Jewish Museum for Moravia-Silesia was officially opened.(8) 


\section{Interiors}

In Horizont magazine we can find the text by Egri himself, written in the form of a letter to the lady who decided to ask the architect to design an interior. The whole letter is a set of advice to a lady on how to communicate with the interior designer. The author is defending the position of interior designer, and we can feel he is talking from his own experience. The originality of the design is important: "Dear Madam, if you have received from your architect a beautiful project, but you haven't seen anything similar anywhere else, don't consider it as bad. ... (The architect) wants to satisfy all your wishes and desires, so that you recognise yourself and your husband in every corner of your apartment. The architect is like a Parisian Haute couture designer, who appreciates the taste of his customers, but doesn't underestimate his own.“(9)

Since apartment interiors were created primarily for the inhabitants and not visitors, designs were based on the owner's taste. Furniture selection was efficient and based on current needs, including multifunctional pieces: an armchair with a folding desk used as a side table (for architect E.) [Img. 1] or a wooden cabinet in the living room served for various purposes - inbuilt secretary desk, liquor section, bookshelf, and card file (part of a living room for Dr. B).

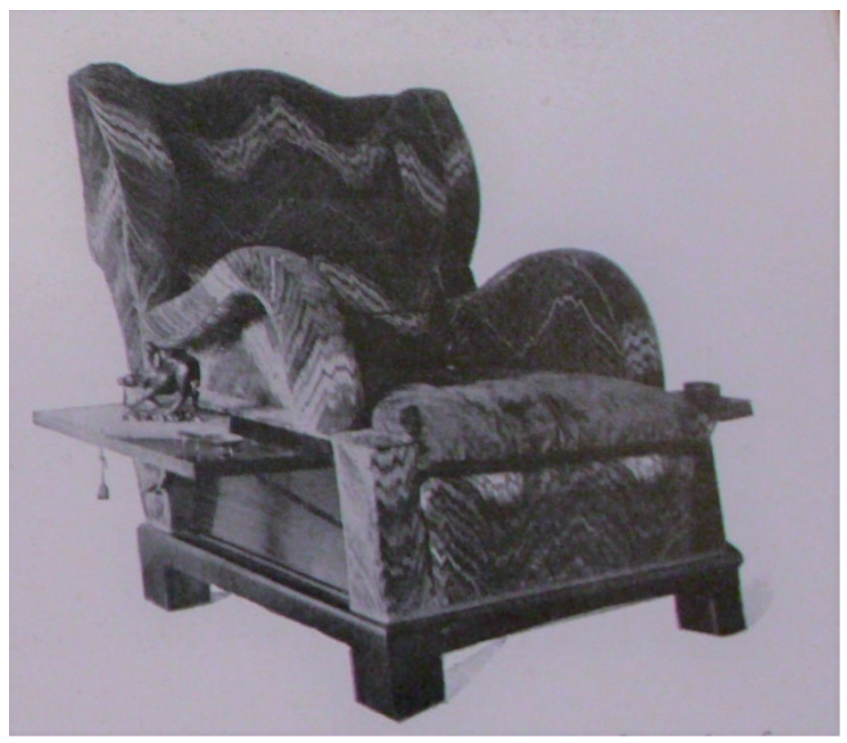

Img. 1. Armchair with a folding desk used as a side table, for architect E., before 1931. Source: BAIER, Vinzenz. Architekt Zoltán Egri, in: Horizont, 1931 (31 - 32), p. 160. 
According to Egri, interiors should be cozy, comfortable, and practical. He designed whole apartments, his original and distinctive style can be seen mainly in the shaping of wooden parts. Apart from padded armchairs, chairs, tables, cabinets, beds, wardrobes, lamps, chandeliers, etc. we can also find produced examples of a hall staircase (villa W.), fireplace (apartment M.), and stucco ceiling (apartment of Dr. K in Mikulov) [Img. 2]. The materials used were of high quality, for example, exotic wood veneers - caucasian walnut, cherry, mahogany, Makassar, etc. Some elements and pieces of furniture can be considered as being in the Art Deco Style.

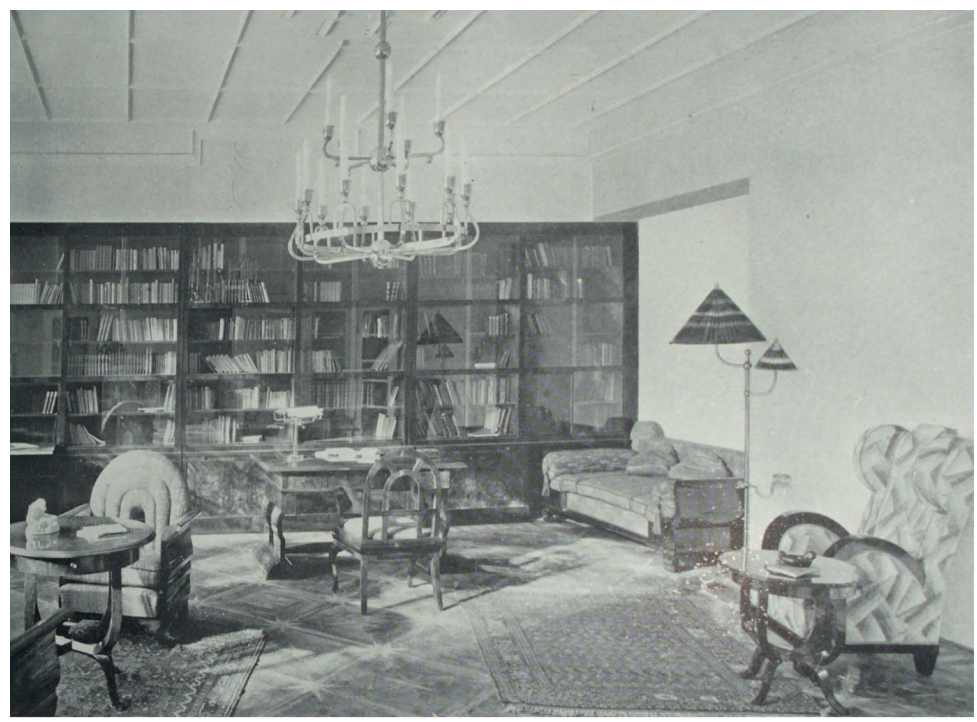

Img. 2. Library for Dr. K, Mikulov, before 1931. Source: BAIER, Vinzenz. Architekt Zoltán Egri, in: Horizont, 1931 (31 - 32), p. 144.

\section{Exhibitions}

In 1928, the Exhibition of Contemporary Culture in Czechoslovakia was held in Brno. The German Werkbund Pavilion was designed by German architect Vinzenz Baier and the interiors by Zoltán Egri and Othmar Frass-Friedenfeldt. Apart from the whole concept of the Werkbund exhibition, Egri designed the Textile department and German - Moravian Association section. As far as we can see from photos, it consisted of exhibition cabinets, chairs, sofa, lamps, wooden staircases, etc.(7) After designing the Werkbund Pavilion, Egri became better known in public and received more commissions. 


\section{Shopfronts}

Egri was the designer of dozens of shopfronts, mainly from the 1930s. Mostly he made adaptations of older portals. According to the article from 1935, the shopkeepers realised products should be presented in a modern environment. Apart from a shopfront with wide glass windows, the best advertisement is provided by using neon light signs. Keeping up with the times is a good way for a shopkeeper to attract new customers. Aspects of a good shop window display are simplicity of form and clarity of layout; there are also some principles on how to arrange goods into a display. The main emphasis is on taste and aesthetics, not only in the shopfront and window displays, but also in the shop interiors.(10)

The architect should be up to date, using new materials, new typology, etc. There are two examples where Egri even readapted shopfronts that he had designed before. After a change of the shop owner, the architect designed a new shopfront in the same place, using mainly new typography and sometimes materials. Before 1931, he made these changes in the shopfront at Freedom Square 15 (Klein's Palace). The iron frame is filled with marble cladding, the Auto-Moravia car accessory shop has just a large shop window, while clothing shop Reithoffer's window consists of more parts, with an entrance in the middle.

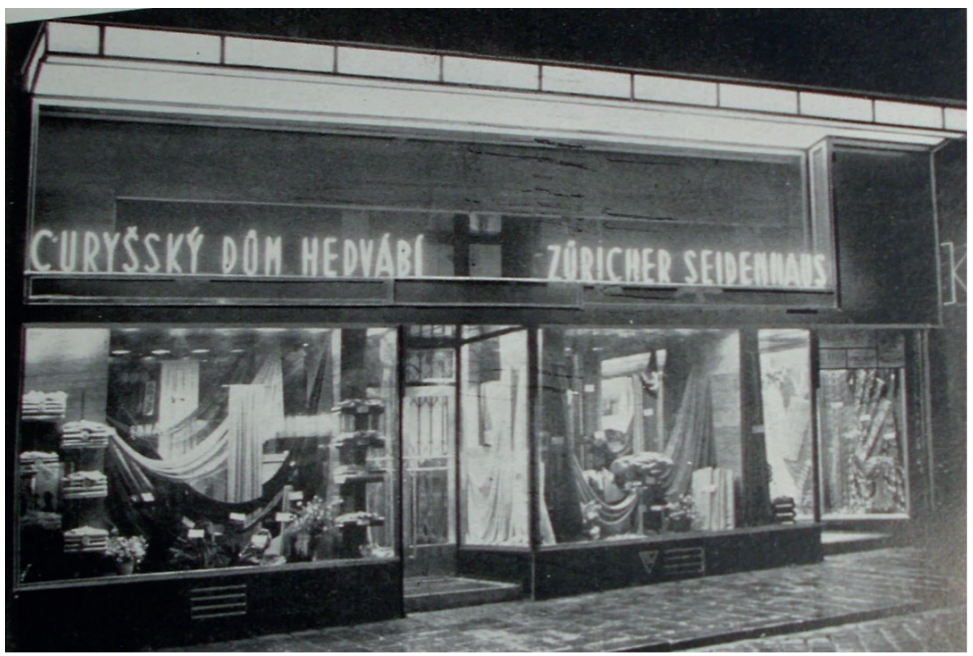

Img. 3. Zurich silk shop, Běhounská street 3/5, 1934. Source: SZ., B. Neue Geschäftsportale, in: Forum, 1935 (5), p. 274. 


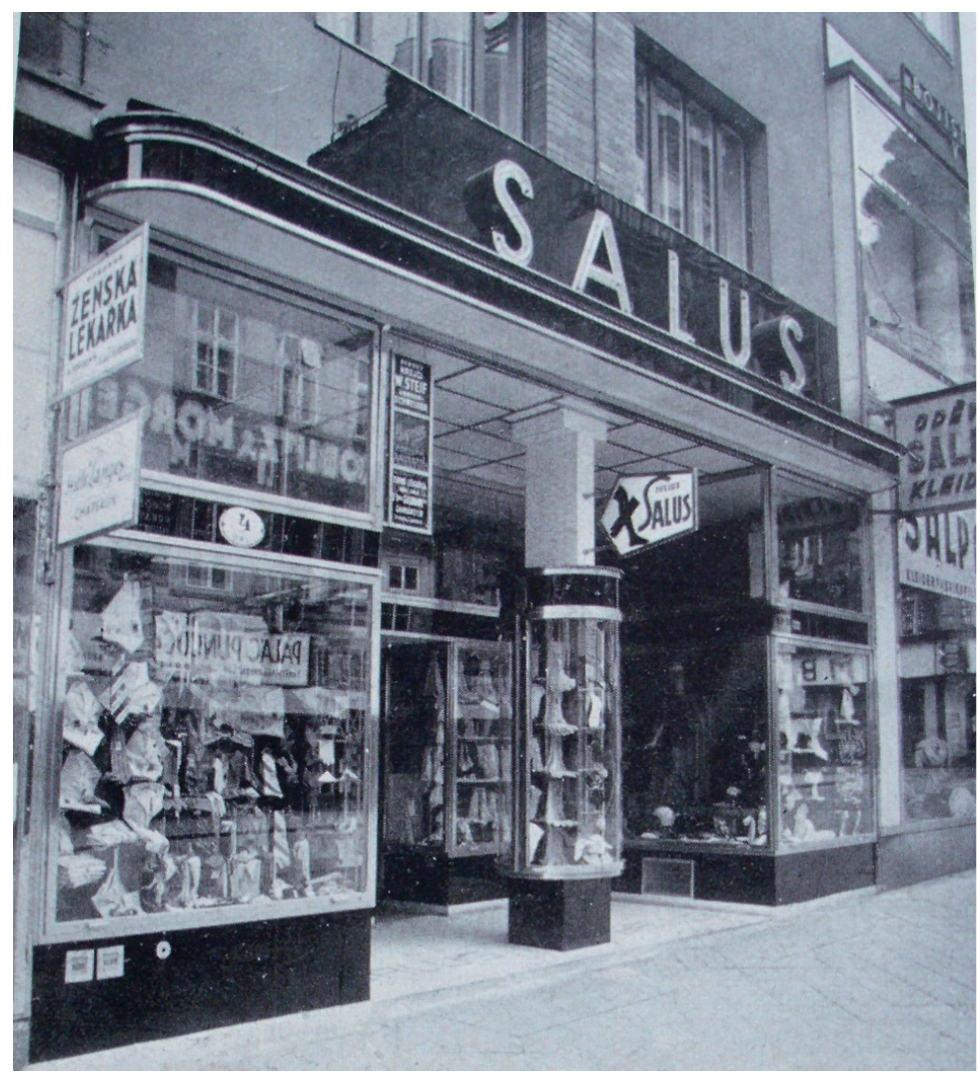

Img. 4. Salus lingerie shop, Orlí street 4, 1937. Source: Neue Portalbauten von Arch. Zoltán Egri, Brünn, in: Forum, 1937 (7), p. 212.

Before 1931, Egri also designed the shopfront for the Cobra leather shop at Masarykova street 8 and re-designed it for the purposes of the Freund silver shop in 1937. The bottom part is made of silver bronze and the Cobra shopfront fascia is made of etched and green-tinted mirror, while the fascia of the Freund shop is made of opaque glass. There is also a significant change in the typography.

A similar stylistic example is the Šmerda bakery shopfront at Údolní street 32, using a combination of iron frame and light grey opaque glass cladding with red signs and neon lights. These were also present and important in the Zurich silk house shopfront at Běhounská street 3/5 from 1934 [Img. 3]. Riveted pillars support the upper floor and make the interior higher. At night, the black shopfront is lit up by a green neon sign and lighting 
canopy above. The whole adaptation was made within six weeks and the newspapers described it as "one of the most beautiful and modern shops in Brno."(11) Egri also designed shop interiors, such as for the Wltžek bookshop at Masarykova street 37/39 (in cooperation with Hans Haas), using the combination of black opaque glass and green signs on the facade, and a wooden shop counter and steel chrome frame shelves in the interior.

One of the latest creations known by Egri is the Salus lingerie shopfront at Orlí street 4, from 1937 [Img. 4]. Apart from the window displays, it consists of a shop entrance as well as one to a house, that is hidden behind the left shop window. In the middle of the shopfront, there is a pillar Egri used as a part of a cylindrical display cabinet. This smart solution helps to raise the attractiveness of the whole shopfront and it is one of the examples of how the architect assists the shopkeeper to achieve effective representation. Shopfronts in general work with psychological aspects, the customers are attracted by large window displays and neon lighting.

\section{Further research}

There are many questions for further research - it is still not known what happened to Egri after 1939, where exactly the apartments he designed were, or who they were owned by. It would also be interesting to find more information about the exhibition of the Jewish Museum in Mikulov, as well as documents related to the company Watterich Egri \& Co. Brünn. Last but not least, what was Egri's place in the group of Jewish architects in Brno? Did they inspire each other?

\section{Conclusion}

To conclude, the paper aims to present my current research about the Jewish architect Zoltán Egri and his work in the interwar period. As an interior designer, he created cozy, practical, and distinctive spaces using elements from the Art Deco style, dark wood veneer, padded armchairs, etc. Egri was the designer of exhibitions for the German Werkbund Pavilion at the Exhibition of Contemporary Culture in Czechoslovakia and an exhibition for the Jewish Museum for Moravia-Silesia in Mikulov. He is probably best known is as the architect of modern shopfronts in Brno city centre, mainly produced with iron frames, opaque glass, and neon lights. He designed the shop interiors as well, always tending to be effective and up to date.

\section{Footnotes}

1. PELČÁK, Petr, Jan SAPÁK a Ivan WAHLA, ed. Brněnští židovští architekti, 1919-1939, Brno: Obecní dům, 2000, p. 13.

2. Brněnské výstavní trhy 8. - 17. 8. 1925: Program, Brno 1925. 
3. PELČÁK, Petr, Jan SAPÁK a Ivan WAHLA, ed. Brněnští židovští architekti, 1919-1939, Brno: Obecní dům, 2000, p. 89.

4. Adresár Protektorátu Čechy \& Morava pro průmysl, živnosti a obchod, Praha: Rudolf Mosse, 1939.

5. Professor at German Technical University at the same time Egri was a student there, also the author of German Werkbund Pavilion.

6. BAIER, Vinzenz. Architekt Zoltán Egri, in: Horizont, 1931 (31 - 32), p. 135, 139.

7. Almanach Výstavy soudobé kulturyv Brně 1928. Brno: Národohospodářská propagace ČSR, 1929, p. $62-63$.

8. VESELSKÁ, Magda. Židovské ústřední museum pro Moravsko-Slezsko v Mikulově, in: Sborník Regionálního muzea v Mikulově, 2005, p. 81.

9. EGRI, Zoltán. Sehr geehrte gnädige Frau! in: Horizont, 1931 (31 - 32), p. 148 - 151.

10. SZ., B. Neue Geschäftsportale, in: Forum, 1935 (5), p. 271.

11. Podnikatelský duch mírní nezaměstnanost. In: Lidové noviny, 1934 (42), 18. 12. 1934, n. 636, p. 6.

\section{Bibliography}

BAIER, Vinzenz. Architekt Zoltán Egri, in: Horizont, 1931 (31 - 32), p. 134 - 163.

BISOM, Wilhelm. Arbeiten von Zoltán Egri, in: Forum, 1932 (2), p. 15 - 20.

SZ., B. Moderne Auslagen, in: Forum, 1931 (1), p. 367 - 372.

SZ., B. Neue Geschäftsportale, in: Forum, 1935 (5), p. 271 - 279.

Neue Portalbauten von Arch. Zoltán Egri, Brünn, in: Forum, 1937 (7), p. 212.

GRYM, Ludvík, Jindřich ŠKRABAL. Lesk a bída portálů. Katalog architektonicky významných portálů v Brně vyhotovený na objednávku Odboru územního a stavebního ř́zení Úradu města Brna a Útvaru hlavního architekta. Brno, 1991.

PELČÁK, Petr. Brněnští němečtí architekti v období první republiky Československa, in: Kontexty, 2013 (5), vol. 6, p. $34-43$.

PELČÁK, Petr, Jan SAPÁK a Ivan WAHLA, ed. Brněnští židovští architekti, 1919-1939, Brno: Obecní dům, 2000.

SEDLÁŘOVÁ, Jaroslava. Německá kultura v Brně 1918 - 1938, in: 49. Bulletin Moravské galerie v Brně, 1993, p. 168.

VESELSKÁ, Magda. Židovské ústřední museum pro Moravsko-Slezsko v Mikulově, in: Sborník Regionálního muzea v Mikulově, 2005, p. 80 - 87.

Almanach Výstavy soudobé kultury v Brně 1928. Brno: Národohospodářská propagace ČSR, 1929, p. $62-63$.

Adresár Protektorátu Čechy \& Morava pro prưmysl, živnosti a obchod, Praha: Rudolf Mosse, 1939.

Brněnské výstavní trhy 8. - 17. 8. 1925: Program, Brno 1925.

Podnikatelský duch mírní nezaměstnanost. In: Lidovénoviny, 1934 (42), 18. 12. 1934, n. 636, p. 6. 